\title{
End Note
}

Since Names was initiated in 1953, editors and succeeding editors have given lip service to the use of the MLA Style Sheet and have recommended it in its several revised editions. Unfortunately, in respect to notes, the membership of the Society comes from many disciplines, and the authors are accustomed to styling endemic to their particular fields. Linguists follow the LSA Style Sheet, which is radically different from the documentation of MLA. Then, the sciences and social sciences have their methods, some requiring "literature cited" or merely looked into. The result is that Names has had no "style" at all, other than that imposed by the different editors, who have been eclectic and perhaps hopeful. Now, the matter is further complicated by the dissatisfaction with the $M L A$ Handbook for Writers of Research Papers, Theses, and Dissertations (1977) and the subsequent "Report of the Advisory Committee on Documentation Style,"' PMLA 97 (1982): 319, which details the difficulties and makes tenative suggestions. The issue of Names you have just looked through was already set in type before the MLA suggestions arrived.

The Editor, Associate Editor, Monograph Editor, and members of the Editorial Board plan to have a style sheet, a short one, ready for authors who are to be published in the 1983 issues of Names. In the meantime, we welcome suggestions from readers and members.

The Editor 